\title{
The prevalence of multiple sclerosis in Santa Maria, Rio Grande do Sul, Brazil
}

\author{
Prevalência de esclerose múltipla em Santa Maria, estado do Rio Grande do Sul, Brasil \\ Alessandro Finkelsztejn', Juarez Silva Lopes², Janaina Noal³, Juliana M. Finkelsztejn ${ }^{4}$
}

\begin{abstract}
Multiple sclerosis (MS) is one of the leading causes of neurologic deficits in young adults and can lead to physical, intellectual and emotional problems. Approved treatments are expensive and are among the 10 highest budgets of the Brazilian Health Ministry. Given the diverse prevalence of MS among Brazilian regions, it is important to determine prevalence rates across the country. Seven studies have assessed MS in Brazil and reported rates ranging from 15 cases to 18 cases per 100,000 inhabitants. It has been hypothesized that this rate is even higher in southern Brazil, which has a high proportion of European heritage (mostly German and Italian) immigrants. Here, we report that the prevalence of MS in the city of Santa Maria, Rio Grande do Sul, Brazil, is 27.2 cases/100,000 inhabitants.
\end{abstract}

Keywords: multiple sclerosis, prevalence, Brazil

\section{RESUMO}

Esclerose múltipla (EM) é uma das principais causas de déficit neurológico em adultos jovens, causando problemas físicos, intelectuais e emocionais. Os tratamentos aprovados estão entre os 10 maiores gastos do Ministério da Saúde em nosso país. 0 conhecimento da prevalência da doença nas diversas regiões brasileiras torna-se essencial. Há sete estudos de prevalência realizados no Brasil, com taxas variando desde 15/100.000 até 18/100.000. Há expectativa de que o sul do Brasil - devido à imigração européia (a maioria alemães e italianos) possa ter taxas até maiores do que 18/100.000. Este estudo mostrou que a prevalência de EM na cidade de Santa Maria, Brasil, é de 27,2/100.000.

Palavras-chave: esclerose múltipla, prevalência, Brasil.

Multiple sclerosis (MS) is a demyelinating inflammatory and degenerative disease of the central nervous system (CNS) with unknown etiology. Given the differences in prevalence rates among populations, it is likely that MS is influenced by an interaction between genetic and environmental factors ${ }^{1}$.

In the last 20 years, a large number of studies on MS prevalence have been published, mostly in Europe and North America, revealing rates ranging from 60 to 200 per 100,000 inhabitants ${ }^{2}$. In Brazil, it is estimated that MS has a prevalence rate of 5-30 cases/100,000. This is based on seven publications thatwhich investigated the prevalence of MS in well-defined geographical areas in Brazil. The first study was carried out in 1990 in the city of Sao Paulo and reported a prevalence rate of 4.3 per 100,000 inhabitants $^{3}$. Later, the same group conducted another study in the same city and described a much higher prevalence rate of 15 per 100,000 inhabitants 4 . The third study reported a rate of 17 per 100,000 inhabitants in the city of Botucatu in the state of Sao Paulo ${ }^{5}$. The fourth in the city of Recife described a rate of 1.36 per 100,000 inhabitants diagnosed with $\mathrm{MS}^{6}$. The fifth study was published in 2007 and was carried out in Santos; it described a rate of 15.5 per 100,000 inhabitants $^{7}$. The sixth study took place in the city of Uberaba in 2011 and reported a rate of 12.5 per 100,000 inhabitants $^{8}$. The most recent publication described a 2012 study carried out in the city of Belo Horizonte, which revealed a rate of 18 per 100,000 inhabitants ${ }^{9}$. However, to the best of our best knowledge there are no publications describing the prevalence in southern Brazil, a region expected to have a higher rate of MS owing to high levels of European immigration from Italy and Germany over the last two centuries.

\footnotetext{
${ }^{1}$ Neurologist, coordinator of the Ambulatório de Esclerose Múltipla at the Hospital das Clínicas de Porto Alegre, coordinator of the Regional Center for Drugs Dispensation for Multiple Sclerosis, Porto Alegre RS, Brazil;

${ }^{2}$ Neurologist, coordinator of the Multiple Sclerosis Treatment Center, Santa Maria RS, Brazil;

${ }^{3}$ Neuropsychologist at the Multiple Sclerosis Treatment Center, Santa Maria RS, Brazil;

${ }^{4}$ Physician, clinical researcher in Ambulatório de Esclerose Múltipla at the Hospital das Clínicas de Porto Alegre, Porto Alegre RS, Brazil.

Correspondence: Alessandro Finkelsztejn, Rua Mostardeiro 05/1002 - CEP: 90430-001 Porto Alegre RS, Brasil. E-mail: alessandro.finkels@gmail.com

Conflict of interest: There is no conflict of interest to declare.

Received 30 May 2013; Received in final form 08 September 2013; Accepted 17 September 2013.
} 


\section{METHOD}

a) Area: the prevalence survey was carried out in the city of Santa Maria, in the state of Rio Grande do Sul, Brazil (Fig. 1 and Fig. 2). The city is located at $29^{\circ} 41^{\prime} 03^{\prime \prime} \mathrm{S}$ and $53^{\circ} 48^{\prime} 25^{\prime \prime} \mathrm{W}$ and covers an area of $1,825 \mathrm{~km}^{2}$ at a mean altitude of $151 \mathrm{~m}$ above sea level. According to the 2010 Brazilian Census from IBGE (Instituto Brasileiro de

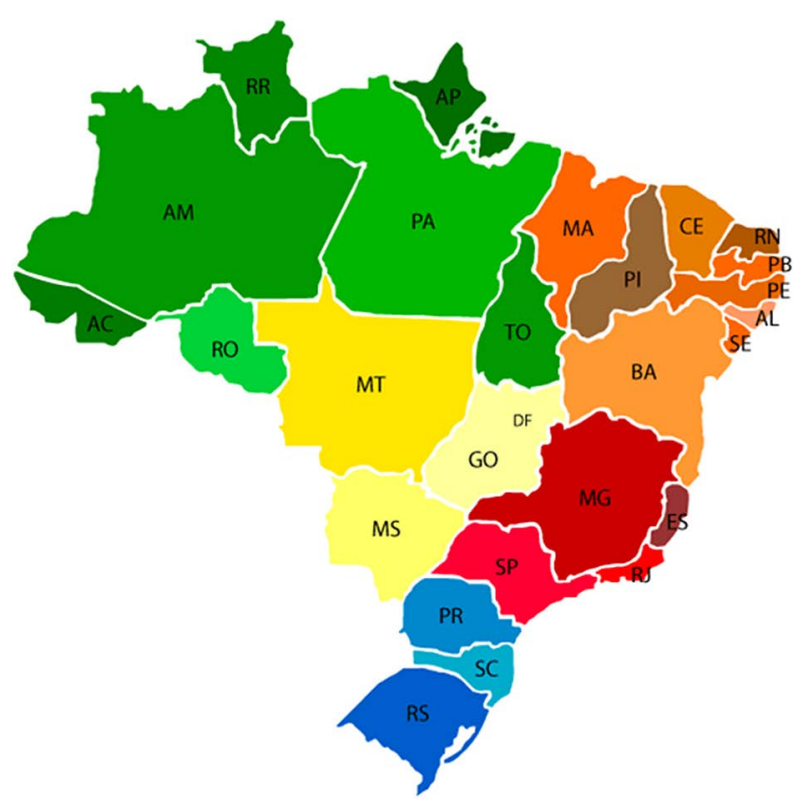

Figure 1. Geographical location of the state of Rio Grande do Sul, Brazil.

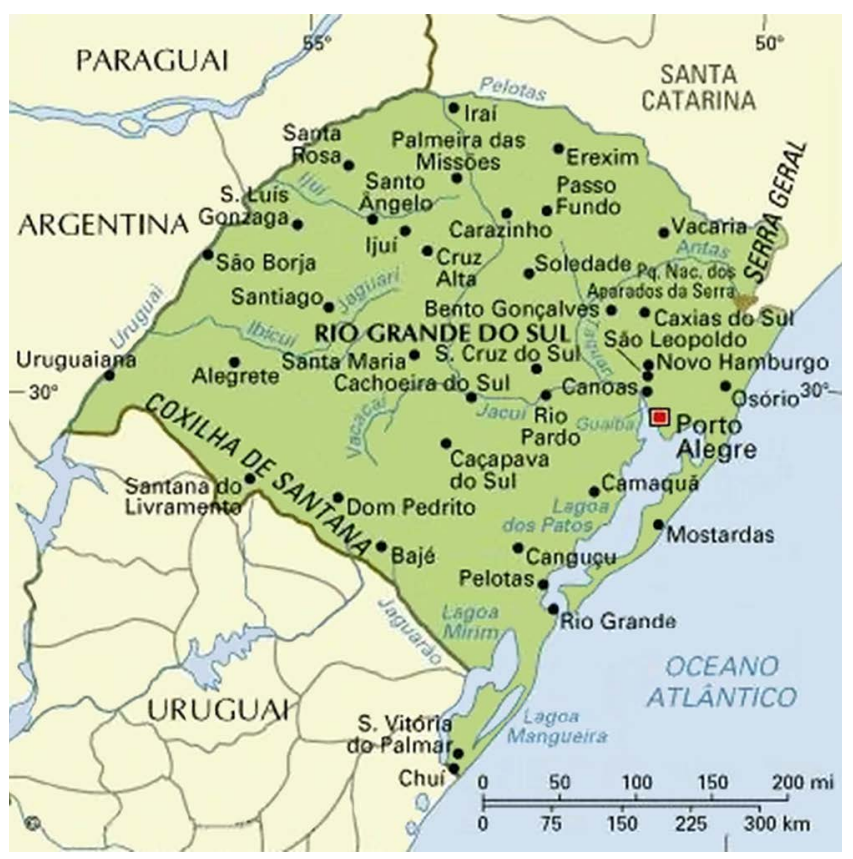

Figure 2. Geographical location of Santa Maria in the state of Rio Grande do Sul, Brazil.
Geografia e Estatística), the estimated population at the time of the survey was 261,031 inhabitants ${ }^{10}$. The city of Santa Maria was chosen for many reasons: it is located in the center of the state, it is a culturally and medically developed city with an excellent magnetic resonance imaging (MRI) clinic, and several neurologists work there. One neurologist (JSL) has been involved in centralizing the diagnosis and treatment of MS patients; he founded a specialized center for MS diagnosis and treatment in the city, where patients served by both public and private health systems are assisted. In addition, he works in close conjunction with "APEMSMAR" (MS Patients Association from Santa Maria). Even if a patient decides to be treated by another neurologist, he/she is almost always registered in the APEMSMAR database.

b) Case ascertainment: Following approval by the local Ethical Committee, these were the sources of identified MS cases: (1) medical records from the author (JSL), (2) files from the city's major general hospitals, (3) files from the largest MRI clinic in the city, and (4) files from APEMSMAR. We only collected patients' initials and birth dates to identify duplicate cases without disclosing the names of MS patients included in the survey. The patients had to be alive and residing in the city of Santa Maria at the time the study was conducted. Details of clinical notes and hospital charts were not collected. Data were checked for duplicate entries by the authors (JN, AF, and JMF).

c) This study was registered at Ethics Committee/Hospital de Clinicas de Porto Alegre, protocol number 100086.

\section{RESULTS}

After quantifying the number of MS cases in the city of Santa Maria, we identified 71 patients with MS who were living in the city at the time of the study. With a total of 261,031 inhabitants, we calculated a crude prevalence rate of 27.2 cases per 100,000 inhabitants. Among these 71 cases, 52 (73.4\%) were female and 19 (26.7\%) were male. Table 1 compares our data and that of existing studies on MS prevalence in Brazil ${ }^{3-9}$.

\section{DISCUSSION}

Our analysis yielded a prevalence rate of 27.2 cases per 100,000 inhabitants in Santa Maria, a representative city of the state of Rio Grande do Sul in southern Brazil. This is the highest prevalence rate reported in Brazil.

There are several possible reasons for this high rate. A higher proportion of the inhabitants have European ancestry, and the city is at a higher latitude than other studied cities, 
Table. Brazilian MS prevalence rates in published studies.

\begin{tabular}{lcc}
\multicolumn{1}{c}{ City } & Author and year & $\begin{array}{c}\text { Prevalence rate } \\
\text { (per 100,000) }\end{array}$ \\
\hline Sao Paulo & Callegaro et al., 1990 & 4.3 \\
Sao Paulo & Callegaro et al., 19974 & 15.0 \\
Botucatu & Rocha et al., 2002 & 17.0 \\
Recife & Brito et al., 2004 & 1.36 \\
Santos & Fragoso et al., 20077 & 15.5 \\
Uberaba & Ribeiro et al., 20118 & 12.5 \\
Belo Horizonte & Lana-Peixoto et al., 2012 & 18.1 \\
Santa Maria & Finkelsztejn et al., 2013 & 27.2 \\
\hline
\end{tabular}

which equates with less solar exposure and higher rates of vitamin $\mathrm{D}$ deficiencies.

It is possible that this rate is overestimated, as an MS patient could be registered in medical clinics in the city of Santa Maria and provide a local address but not be an actual resident there. This can happen for eaubureaucratic reasons that are beyond the scope of this article.

On the other hand, when considering the possibility that this rate could be underestimated, it is possible that economically well-off individuals with MS who lives in Santa Maria might prefer to seek medical assistance in bigger cities, owing to their belief that they could receive better care. These patients would not be included in the registers and would not have been quantified in the present study.

One strength of our study is that it is the first to be carried out in southern Brazil, and the results can help government and health insurance companies to plan for investments in the health promotion of individuals with MS.

A limitation of our study was the methodology used to identify MS cases in Santa Maria. For example, we failed to seek registers at all the hospitals in the city. This occurred was because one of the authors (JSL) works in both of the most important hospitals in the city, which treat more than $90 \%$ of all inpatients in the city area, and is a consultant in cases of suspected MS. So, even though we did not access all hospital register, we are confident that we had access to the data of all MS patients evaluated by JSL, irrespective of whether they were treated as inpatients or outpatients.

Finally, we hope that more studies with improved methodology will be carried out to assess MS prevalence rates in Brazil; such research will clarify the nationwide distribution of MS patients.

\section{Acknowledgements}

We would like to acknowledge the contribution of the MS Patients Association from Santa Maria (“APEMSMAR”).

\section{References}

1. Poser CM, Brinar VV. The accuracy of prevalence rates of multiple sclerosis: a critical review. Neuroepidemiology 2007;29:50-55.

2. Rosati G. The prevalence of multiple sclerosis in the world: an update. Neurol Sci 2001;22:117-139.

3. Callegaro D, de Lolio CA, Radvany J, Tilbery CRP, Mendonça RA, Melo AC. Prevalence of multiple sclerosis in the city of Sao Paulo, Brazil, in 1990. Neuroepidemiology 1992;11:11-14.

4. Callegaro D, Goldbaum M, Tilbery CP, et al. The prevalence of multiple sclerosis in the city of Sao Paulo, Brazil, 1997. Acta Neurol Scand 2001;104;208-213.

5. Rocha FC, Herrera LC, Morales RR, The Brazilian Committee for Treatment and Research in Multiple Sclerosis. Multiple sclerosis in Botucatu, Brazil. A population study. Mult Scler 2002;8(Suppl):S41-S42.
6. Ferreira MLB, Machado MIM, Vilela ML, et al. Epidemiologia de 118 casos de esclerose múltipla com seguimento de 15 anos no Centro de referência do Hospital da Restauração de Pernambuco. Arq Neuropsiquiatr 2004;62:1027-1032.

7. Fragoso YD, Peres M. Prevalence of multiple sclerosis in the city of Santos, SP. Rev Bras Epidemiol 2007;10:479-482.

8. Ribeiro SBF, Maia DF, Ribeiro JB, et al. Clinical and epidemiological profile of patients with multiple sclerosis in Uberaba, Minas Gerais, Brazil. Arq Neuropsiquiatr 2011;69:184-187.

9. Lana-Peixoto MA, Frota, ERC, Campos GB, Monteiro LP, on behalf of the Brazilian Committee for Treatment and Research in Multiple Sclerosis. The prevalence of multiple sclerosis in Belo Horizonte, Brazil. Arq Neuropsiquiatr 2012;70:102-107.

10. http://www.ibge.gov.br/cidadesat/link. php?codmun $=431690$ (accessed 15 May 2013). 